ISBN 978-93-84468-80-4

International Conference on Agricultural, Biological and Environmental Sciences

(ICABES-2016)

Pattaya (Thailand) Dec. 14-16, 2016

\title{
Virus Diseases of Edible Seed Squash (Cucurbita pepo L.) in Turkey
}

\author{
Serkan Yeşi $1^{1}$ \\ ${ }^{1}$ Department of Plant Protection, Faculty of Agriculture, Selçuk University, Konya, Turkey
}

\begin{abstract}
Squash seeds have been used as a snack in Turkey like in some Mediterranean countries and Germany, Hungary, Austria and China. Viral diseases are very destructive especially on squash (Cucurbita pepo L.) which is grown for seeds in some provinces of Turkey such as Kayseri, Konya, Nevşehir, Aksaray, Karaman, and Niğde. In Turkey, edible seed squash is economically important but has a high incidence of virus-like symptoms. Viruses causing mosaic, leaf deformation, fruit deformation and reduced growth were observed in squash plants in the growing areas. In previously researches, Zucchini yellow mosaic Potyvirus (ZYMV), Watermelon mosaic Potyvirus-2 (WMV-2), Cucumber mosaic Cucumovirus (CMV), Papaya ringspot Potyvirus-watermelon strain (PRSV-W), and Squash mosaic Comovirus (SqMV) were determined on edible seed squash plants. Especially, it is known that ZYMV and WMV-2 were the most prevalent viruses on the plants. The most important reason of this problem is nonexistence of certified variety. So, the growers have to use own seeds or they obtain from other growers. Because the viruses can be transmitted by squash seeds, the virus diseases occur on squash plants every year. Even if the viruses have limited transmission capacity by squash seeds, this situation is really causes survive of the viruses year by year. Therefore, using of non-infected and healthy crop seeds is tremendously important in plant production and control of virus diseases. In this study, symptoms, other host plants, transmission mechanisms and control of the squash viruses in Turkey was briefly summarized.
\end{abstract}

Keywords: CMV, Edible seed squash, Seed transmission, Turkey, WMV-2, ZYMV.

\section{Introduction}

Cucurbits (the Cucurbitaceae family) include 119 genera and 825 species distributed primarily in tropical and subtropical regions of the world (1). The major cultivated cucurbit species such as melon (Cucumis melo L.), cucumber (Cucumis sativus L.), squash (Cucurbita pepo L.), and watermelon (Citrullus lanatus (Thunb) Matsum.\&Nakai) are important vegetable crops worldwide. As in many parts of the world, squash is produced for fruit, as well as for seeds and flowers. The seeds of the vegetable species in Cucurbitaceae have been used as snacks in various regions of Turkey for many years. In the Southeastern Anatolia region of the country, watermelon and melon seeds are consumed as snacks as well as squash seeds (2). It is stated that the growing of edible seed squash has entered and spread to the country through the Thrace region (3). They occupied 51.580 ha in the country during 2013, with an estimated production of 35.586 tons (4). The cultural practices adapted by the growers, environmental conditions that are conducive for epidemic development and, moreover, the lack of awareness of growers about the viral diseases are some of the major factors that result in a high incidence of the viral diseases. Also, most growers use seed from uncertified sources, which provide primary sources of inocula at a very early stage thus resulting in a rapid spread of the viral diseases. Edible seed squash growing has some advantages compared to other squashes. Such as; no need to frequent irrigation or growing in completely barren conditions, suitable for crop rotation, the ease of harvesting, the possibility of using machineries in growing and not much problem in terms of diseases and pests. In Turkey, generally, Cucurbita pepo L. is used for cultivating of edible seed squash, but occasionally, Cucurbita moschata species also used for growing of edible seed squash (3). 
Diseases and pests are the main problems encountered during the production of cucurbit plants. Zitter (1996) has reported that there are more than 200 diseases which cause important loss in yield and quality on cucurbit vegetable species (5). Especially, virus diseases have a significant importance compared to other diseases in cucurbits. Indeed, more than 35 different viruses have been isolated from cucurbits (6). Cucurbit viral diseases are a problem worldwide and an analysis at the University of Hawaii showed that growers considered aphid transmitted viruses to be one of the most important limiting factors that can cause losses as high as $100 \%$ (7). On a worldwide basis, potyviruses badly affect cucurbit cultivation and the three most frequent and economically important potyviruses are Zucchini yellow mosaic Potyvirus (ZYMV), Watermelon mosaic Potyvirus-2 (WMV-2) and Papaya ringspot Potyvirus-watermelon strain (PRSV-W) (8). Cucumber green mottle mosaic Tobamovirus (CGMMV), Cucumber mosaic Cucumovirus (CMV), Squash mosaic Comovirus (SqMV) and Melon necrotic spot Carmovirus (MNSV) have also long been known to be important viruses infecting cucurbit crops (9). These viruses occur in complexes and so cause dynamically changing problems (10).

There has been one report on the detection of viruses from edible seed squash fields in Turkey. With this research, ZYMV, WMV-2, CMV, SqMV, and PRSV-W were detected in Turkey. According to the results of the research, ZYMV was the prevalent virus with \%60,18 incidence, and WMV-2 followed it with \%52,99. Also, in this research, double and multiple infections were common (11).

\section{Viruses of Edible Seed Squash}

\subsection{Cucumber mosaic Cucumovirus (CMV)}

\subsubsection{Geographic distribution}

It was first described as a disease of cucurbits in 1916 by Doolittle in Michigan and Jagger in New York. The virus can infect a large number of indicator plant species and has been isolated from over 500 naturally infected species. The virus is common everywhere where cucurbits are grown. CMV isolates have a worldwide distribution, having been reported from both temperate and tropical regions. Most reported isolates belong to subgroup I. Subgroup II isolates are found more frequently in cooler areas or seasons of temperate regions (12, 13).

\subsubsection{Symptoms and host range}

Although, it's known that all cucurbits are sensitive to CMV, the virus is rarely observed on watermelon. The severity of symptoms is at least partially related to the virus concentration. Cucurbit plants rarely become infected in the seedling stage. When this happens, the cotyledons may turn yellow and wilt. New leaves are slightly mottled a yellowish green; remain small, wrinkled, and distorted. Plants infected in the seedling stage remain dwarfed or may die, and seldom produce fruit. CMV can cause different symptoms on edible seed squash such as, stunting due to shortening internodes, yellow mosaic or mottling, distortion, and wrinkling on leaves. On young plants leaves, some systemic symptoms are observed as, curled downward, mosaic, rosetting, and dwarfing and narrowing of lamina. Also, on flowers of severely infected squash plants, abnormalities can be seen and petals become green as leaves. Squash fruit may be mottled and warty with raised areas lighter in color than surrounding tissue $(13,14)$.

The virus causing cucumber mosaic has, perhaps, a wider range of hosts and attacks a greater variety of vegetables, ornamentals, weeds, and other plants than any other virus. The host range of CMV is over 1300 species in more than 500 genera of over 100 families, with new hosts reported each year. Some recently described strains from new hosts have lost the ability to infect many of the typical hosts of CMV. This may be a general feature for adaptation to unusual hosts. CMV infects most of the major horticultural crops as well as many weed species; the latter act as reservoirs for the virus. Among the most important vegetables affected by cucumber mosaic are cucumbers, gladioli, melons, squash, peppers, spinach, tomatoes, celery, beets, beans, bananas, and crucifers. Common hosts of CMV in Cucurbitaceae are edible seed squash, zucchini squash, cucumber, and melon $(13,14,15)$.

\subsubsection{Transmission}

Although, there aren't so many reports about squash seed transmission of CMV, it's determined that the virus can be transmitted in other 19 host species except of cucurbits hosts. Seed transmission of CMV has been 
reported in many plant species, with efficiencies varying from less than $1 \%$ up to $50 \%$. Virus may be present in the embryo, endosperm, and seminal integuments, as well as in pollen. CMV is transmitted by aphids in a nonpersistent manner. Over 80 species of aphids have been reported to transmit CMV, Aphis gossypii and Myzus persicae being two efficient and most studied vectors. Also, this virus can be transmitted by infected plant sap, mechanically $(12,13,14,16)$.

The virus overwinters in many perennial weeds, flowers, and crop plants. Perennial weeds harbor the virus in their roots during the winter and carry it to their top growth in the spring, from which aphids transmit it to susceptible crop plants. Once a few plants have become infected with CMV insect vectors and humans during their cultivating and handling of the plants spread the virus to many more healthy plants. Entire fields of cucurbits sometimes begin to turn yellow with mosaic immediately after the first pick has been made, indicating the ease and efficiency of transmission of CMV mechanically through sap carried on the hands and clothes of workers $(12,14,16)$.

\subsection{Watermelon mosaic Potyvirus -2 (WMV-2)}

\subsubsection{Geographic distribution}

Watermelon mosaic virus-2 (WMV-2) belongs to the genus Potyvirus in the family Potyviridae. The virus was first described by Webb and Scott (1965) on squash in Florida (28). The virus can cause economically important losses in the quality and quantity in several horticultural crops, mostly cucurbits. The geographical distribution of the virus is not systematical and it depends on climatic conditions. Although, the virus is common in temperate climate and subtropic areas of the world, it can be observed everywhere where cucurbits are grown $(12,14)$.

\subsubsection{Symptoms and host range}

Symptoms of the virus on squash are very variable about the host cultivar, the isolate and environmental conditions. On leaves, symptoms are mosaics, vein banding, more or less severe leaf deformations, and filiformy (shoestring). Some isolates induce discoloration and deformation on fruits of edible seed squash while other isolates do not affect fruit and yield quality. Mosaic and discoloration are also observed on leaves and fruits of some melon cultivars $(12,14)$.

WMV infects over 170 species in 26 mono or dicotyledonous families. Especially, the virus can infect squash, watermelon and melon. Besides cucurbits, WMV-2 causes mosaic diseases in legumes (pea, broad bean) and orchids (vanilla, Habenaria radiata) and infects many weeds that can serve as alternative hosts. Generally, naturally infected weeds do not present evident symptoms of viral infection (14).

\subsubsection{Transmission}

At least 29 species of aphids, including Myzus persicae (Sulzer) and Aphis craccivora Koch, transmit the virus in a non-persistent manner (17). It is also transmitted by mechanical inoculation on more than 170 plant species belonging to 27 families (18).

\subsection{Zucchini yellow mosaic Potyvirus (ZYMV)}

\subsubsection{Geographic distribution}

ZYMV is a particularly notorious virus (19) and since its first appearance in Italy and France, in 1973 and 1979, respectively, it has been reported in 50 countries both in traditional and intensive growing conditions (20). The virus probably occurs worldwide and the most common virus on edible seed squash in Turkey (11).

\subsubsection{Symptoms and host range}

Symptoms consist of severe mosaic, yellowing, shoestring, stunting, and distortions of fruit and seed. Early symptoms in infected zucchini appear as vein clearing of fine leaf veins, followed by a general yellowing of the leaf with dark green areas. Later on, the mosaic becomes stronger, and vein banding appears. Leaves can be deformed to shoestring appearance, but the most affected are fruits, that are severely malformed and often develop longitudinal cracks. Similarly, squash and pumpkin plants develop knobby areas on the fruits resulting in prominent deformations. Seeds are occasionally severely deformed and have poor germination rates. Fruits are generally severely misshaped with prominent knobs and are of course unmarketable. ZYMV has a relatively 
narrow host range. In natural conditions, it infects mostly cultivated or wild cucurbits but also a few flower species (Delphinium, Althea) or weeds $(19,20,21)$.

\subsubsection{Transmission}

ZYMV is spread in a non-persistent manner by a number of aphid species (Aphis citricola, A. gossypii, Macrosiphum euphorbiae and Myzus persicae), and easily transmitted mechanically. In areas where cucurbits are not grown continuously, the virus overwinters on wild species $(19,20,21)$.

\subsection{Papaya ringspot Potyvirus (PRSV-W)}

\subsubsection{Geographic distribution}

Type $\mathrm{W}$ isolates have been reported in cucurbits in many areas including the USA, Mexico, the Caribbean islands, Australia, Germany, France, Italy, India, countries of the Middle East, and South America (21). PRSV$\mathrm{W}$ causes significant yield reduction in watermelon, melon, cucumber, and squash (22). In Florida, yield loss to the virus was up to $100 \%$ in summer squash (Cucurbita pepo) and watermelon (23) with early infections of PRSV-W.

\subsubsection{Symptoms and host range}

The virus causes curled downward, mottling, mild or severe mosaic, and discolorations on leaves. Also, circular, ring spots and deformations are observed on squash fruits.

The virus is reported to infect 38 species in 11 genera of Cucurbitaceae, and two species of Chenopodiaceae, with squash, watermelon, cucumber, and cantaloupe among the commercially important natural hosts. It appears to over winter in wild species of Cucurbitaceae and Chenopodiaceae $(22,24)$.

\subsubsection{Transmission}

PRSV-W is transmitted in a non-persistent manner by 24 aphid species in 15 genera with Myzus persicae, Aulacorthum solani, Aphis craccivora, and Macrosiphum euphorbiae as natural vectors. The virus is not seed transmitted $(23,24)$.

\subsection{Squash mosaic Comovirus (SqMV)}

\subsubsection{Geographic distribution}

Widely distributed in Western Hemisphere, one report from Israel. Because it is seed-borne it has probably been introduced wherever seeds have been imported from the Western Hemisphere. Unless insect vectors are present, it probably will not spread in new localities $(14,22)$.

\subsubsection{Symptoms and host range}

The first symptoms on squash, pumpkin, and zucchini include vein clearing and a yellowish spotting of the younger leaves. Infected leaves tend to cup upward and develop a light and dark green mottling. Squash leaves may appear severely distorted, even threadlike, with regular marginal projections from the veins. Leafy outgrowths or enations may develop on the lower leaf surface. Summer squash fruit are malformed with raised, domelike swellings. The host range of this virus appears to be confined to cucurbits and some members of the Chenopodiaceae (14).

\subsubsection{Transmission}

Insect vectors of SqMV include Acalymma trivittata, Diabrotica undecimpunctata, Acalyma thiemei thiemei and Epilechna chryssomelina. Aphids and other insects are not vectors of the virus.The planting of infected seed is considered the most important primary source of inoculum. Plants grown from infected seed serve as inoculum for secondary disease cycles. This virus has become much less prevalent as more growers have begun to use certified virus free seed. Insecticide applications to control the beetle vectors are also helpful $(14,22)$.

\subsection{Control of the Viruses}

Virus diseases are in general more challenging to control than other disease groups. Most management programs focus on the vector for the virus because there are no pesticides that target viruses. Insecticides applied 
for insect vectors, however, are often ineffective when the virus can be transmitted quickly (25). Floating row covers have been used to prevent insects from getting to the crop. This practice has been found more effective than others (26).

Significant yield increase over non-treated plants was also obtained with cross protection using a mild strain of ZYMV. A good level of protection against virus diseases is being obtained in Lebanon with a combination of insect-proof nets, sticky yellow traps and application of insecticides including imidacloprid (27).

The rate of spread of aphid-transmitted viruses may be reduced by the use of an aluminum reflective mulch to repel aphid vectors, one or two weekly applications of a mineral oil emulsifier combination, and wheat grown in and around cucurbit plantings as a "protection crop". The wheat attracts the infectious aphids and their feeding presumably dilutes the virus during successive probes so much of its infectivity is lost. The wheat causes little shading, is attractive to aphids, does not serve as a host for aphid reproduction, is not a host for most cucurbit viruses or other vine crop pests, and can be easily removed.

Weeds play an important role on virus epidemiology and are a common problem in squash-growing areas in the Turkey. In order to control the virus infection, weeds should be controlled.

Certified and virus-free squash seeds should be used, whenever possible. Do not grow a cucurbit crop adjacent to a mosaic affected one.

Avoid touching healthy plants after handling mosaic-affected plants. If this is necessary, first wash hands thoroughly with hot running water and strong soap. Better still, use a solution of trisodium phosphate (2 tablespoons dissolved in 1 quart of water).

Cultural practices are very important in cucurbits. For this purpose, cultural practices such as sowing, fertilizing and irrigation should be performed properly.

Virus infected plants should be destroyed promptly to prevent them from serving as sources of further infections.

\section{References}

[1] T. C. Andres, 2004: Web site for the plant family Cucurbitaceae \& home of The Cucurbit Network. http://www.cucurbit.org/family.html. Accessed on 23.05.2016

[2] .R, Yanmaz, “Kabakgil Tohumları Deyip Geçmeyin”, Agroskop, vol. 25, pp. 40-43, 2013.

[3] R. Yanmaz and B, Düzeltir, “Çekirdek Kabağı Yetiştiriciliği”, Ekin, vol. 7(6), pp. 22-24, 2003.

[4] Anonymous, 2014. Production values of cucurbits in Turkey, during 2013, www.tuik.gov.tr

[5] T.A. Zitter, "Cucurbit Diseases" in Compendium of Cucurbit Diseases, Edit by T.A. Zitter, D.L. Hopkins and L.E. Thomas, APS Press, St. Paul Mn, USA, 1996, pp. 1-2.

[6] R. Provvidenti, "Diseases caused by viruses". In: Compendium of Cucurbit Diseases, Zitter TA, Hopkins DL, Thomas CE (eds), Minnesota, USA, APS Press, 1996, pp. 37-45.

[7] D.E. Ullman, J.J. Cho, and T.L. German, "Occurrence and distribution of cucurbit viruses in the Hawaiian Islands", Plant Dis., vol 75, pp. 367-370, 1991.

https://doi.org/10.1094/PD-75-0367

[8] H Lecoq, G. Dafalla and C. Desbiez, "Biological and molecular characterization of Morrocan watermelon mosaic virus and a potyvirus isolate from eastern Sudan”, Plant Disease, vol. 85, pp. 547-552, 2001.

https://doi.org/10.1094/PDIS.2001.85.5.547

[9] O. Lovisolo, "Virus and viroid diseases of cucurbits", Acta Horticulture, vol. 88, pp.33-63, 1980.

[10] S. T. Nameth, J. A. Dodds, and A. O. Paulus, "Cucurbit viruses of California", Plant Disease, vol. 70 (1), pp. 8-11, 1986.

https://doi.org/10.1094/PD-70-8

[11] S. Yeşil, "Virus Diseases of Edible Seed Squash (Cucurbita pepo L.) in Konya Province, Turkey" presented at the Agrosym-2014, Bosnia-Herzegovina, October 23-26, 2014.

[12] G. N. Agrios, ’Plant diseases caused by viruses", in Plant Pathology, pp. 479-556, 1997. 
[13] F. Garcia-Arenal, and P Palukaitis, "Cucumber mosaic virus", in Desk of Encylopedia of Plant and Fungal Virology, edited by BWJ Mahy and MHV Van Regenmortel, Elsevier, pp. 171-176, 2010.

[14] M. Babadoost, "Mosaic Diseases of Cucurbits" Report on Plant Disease. Department of Crop Sciences University of Illinois at Urbana-Champaign. 1999.

[15] P. Caciagli, "Vegetable Viruses", in Desk of Encylopedia of Plant and Fungal Virology, edited by BWJ Mahy and MHV Van Regenmortel, Elsevier, pp. 479-487, 2010.

[16] P. Palukaitis, et al., "Cucumber mosaic virus”, Adv. Virus Res, vol.41, pp. 281-348, 1992. https://doi.org/10.1016/S0065-3527(08)60039-1

[17] J.R. Edwardson, and R.G. Christie, "Cucumoviruses" in Viruses Infecting Forage Legumes, J.R. Edwardson and R.G. Christie (eds.). Monogram 14, IFAS, University of Florida, Gainesville, Florida, USA, pp: 143-215, 1986.

[18] D.D. Shukla, C.W. Ward, and A.A. Brunt, The potyviridae, CAB International, pp: 515, Wallingford, UK, 1994.

[19] H. Lecoq, V. Lisa and G. Dellavalle, "Serological identity of Muskmelon yellow stunt and Zucchini yellow mosaic viruses", Plant Disease, vol. 67, pp.824-825, 1983.

https://doi.org/10.1094/PD-67-824

[20] C. Desbiez, and H. Lecoq, “Zucchini yellow mosaic virus”, Plant Pathology, vol. 46, pp.809-829, 1997. https://doi.org/10.1046/j.1365-3059.1997.d01-87.x

[21] D.E. Purcifull, W.C. Adlerz, G.W. Simone, E. Hiebert, and S.R. Christie, "Serological Relationships and Partial Characterization of Zucchini Yellow Mosaic Virus Isolated From Squash in Florida”, Plant Dis., vol. 68, pp. 230-233, 1984.

https://doi.org/10.1094/PD-69-230

[22] H. Lecoq, G. Wisler, and M. Pitrat, "Cucurbit viruses: The classics and the emerging", pp. 126-142. Cucurbitaceae '98, evaluation and enhancement of cucurbit germplasm (Ed. J. D. McCreight). ASHS Press, Alexandria, VA, 1998.

[23] G. Sowell, and J.W. Demski, "Susceptibility of watermelon cultivars to watermelon mosaic virus-2", Plant Dis. Rep. vol.53, pp. 208-209, 1969.

[24] D.E. Purcifull, and E. Hiebert, "Serological distinction of watermelon mosaic virus isolates", Phytopathology, vol. 69, pp.112-116, 1979.

https://doi.org/10.1094/Phyto-69-112

[25] B. Berdiales, J. J. Bernal, E. Saez, B. Woudt, F. Beitia, and E. Rodriguez Cerezo, "Occurrence of cucurbit yellow stunting disorder virus (CYSDV) and beet pseudo-yellows virus in cucurbit crops in Spain and transmission of CYSDV by two biotypes of Bemisia tabaci”, European Journal of Plant Pathology, vol.105, pp. 211-215, 1999. https://doi.org/10.1023/A:1008713629768

[26] S. El Zammar, Y. Abou Jawdah, and H. Sobh, "Management of virus diseases of squash in Lebanon", Journal of Plant Pathology, vol.83, pp. 21-25, 2001.

[27] Y. Abou Jawdah, H. Sobh, A. Fayad, H. Lecoq, B. Delecolle, and J. Trad Ferre, "Cucurbit yellow stunting disorder virus: A new threat to Cucurbits in Lebanon”, Journal of Plant Pathology, vol.82 pp.55-60, 2000.

[28] R.E Webb, and H.A. Scott, "Isolation and identification of watermelon mosaic viruses 1 and 2", Phytopathology, vol.55, pp. 895-900, 1965. 